\title{
The impact of early media election calls on Republican voting rates in Florida's western Panhandle counties in 2000
}

\author{
JOHN R. LOTT, JR \\ American Enterprise Institute, NW Washington, DC 20036, U.S.A.
}

Accepted 11 February 2004

\begin{abstract}
Using voting data for presidential elections from 1976 to 2000, this paper documents an unusual and large drop off in Republican voting rates for Florida's western Panhandle during the 2000 General Elections. Little change appears to have occurred in the rate that nonRepublicans voted. The results appear more consistent with the early call reducing Republican voting rates than the networks discouraging all voters from voting by incorrectly calling the polls closed in the western Panhandle.
\end{abstract}

\section{Introduction}

Despite the national debates over early election calls in 1980, 1996, and 2000, empirical work on how early network election night calls influence the outcome of elections has proved very problematic. Part of the problem undoubtedly arises from the difficulties in making comparisons across states in 1980 and 1996. It is simply extremely difficult to account for all the factors that can be varying across states (e.g., the impact of state election races). The 2000 election, however, provides an interesting opportunity because the Florida election was called by the national media as being over, while polling places in the 10 western Panhandle counties were still open. While comparing different counties within a state at least helps account for the impact of state-level campaigns, the problem is still not completely resolved even here, because one must determine whether any change in voting behavior is actually a result of unique circumstances in a few of the counties. Ultimately, the question is whether something unusual is occurring in all the affected counties.

While this issue was raised in Bush versus Gore, the legal turmoil over the 2000 election is still being felt today. Shortly before the November 2002 election, a federal court in Florida even issued an injunction preventing news organizations from reporting that polling places were closed when they were not. During 2003 private anti-trust action as well as action under state deceptive and unfair trade practices was being taken against the Voter News Service to dissolve it.

The impact that the media had on voting rates in Florida's western Panhandle has been fiercely debated. Florida polls were open until $8 \mathrm{pm}$ on election eve. The problem was that Florida's 10 western panhandle counties are on Central, not Eastern, time. When polls closed at 8 pm EST in most of the 
state, the western Panhandle polling places were still open for another hour. Yet, at $8 \mathrm{pm}$ Eastern time, all the networks (ABC, CBS, CNN, FOX, MSNBC, and NBC) incorrectly announced many times over the next hour that the polls were closed in the entire state. ${ }^{2}$ For example, CBS national news made " 18 direct statements in one hour that the polls had closed and another 15 implying the Florida vote was over." 3

The results of two major races were also in fact called by the networks prior to the polls closing in the western part of the state (Perrin, 2001). The Florida Senate race was called for the Democrats by the networks $58 \mathrm{~min}$ before the polls closed and the presidential race was also called for the Democrats $12 \mathrm{~min}$ before the polls closed (Mason, Frankoviz, \& Jamieson, 2001, p. 16).

Polling conducted after the election confirms that the media had an impact on voter behavior and the perception of Democratic wins discouraged Republican voters. Democratic strategist Bob Beckel concluded Mr. Bush suffered a net loss of up to 8000 votes in the heavily Republican western Panhandle after Florida was called early for Gore. ${ }^{4}$ Another survey of western Panhandle voters conducted by John McLaughlin \& Associates, a Republican polling company, immediately after the election estimated that the early election call cost Bush approximately 10,000 votes. ${ }^{5}$

These incorrect premature calls could have had a substantial impact. The economic theory that an early call could reduce the return to voting is very straightforward. ${ }^{6}$ Indeed, a simple regression of the total presidential vote in each county on a dummy for the affected Panhandle counties in 2000 as well as year and county fixed effects implies a significant $4 \%$ drop in turn out. Anecdotal evidence indicates that the usually heavy voting that takes place during the last hour polls are open fell dramatically during the November 2000 election. Quotes from many clerks for elections and poll workers in the western Panhandle consistently make these points. Here are just a few of the quotes (Perrin, 2001):

Poll Worker, Bay County, Precinct No. 23: "I have been a poll worker since the 1970's. Voting was steady all day until 6:00 pm. Between 6:00 and 7:00 pm it was very different from past elections. It was very empty. The poll workers thought it was odd. It was like 'the lights went out.' We joked with the deputy on duty because there was no one in line for the deputy to be placed behind, when the polls closed."

Clerk for Elections, Okaloosa County, Precinct No. 37: "We had over 1300 people turn out with an average of about 100 voters per hour until the last hour. When the doors were open, there were quite a number of people waiting in line to vote. There was a heavy flow throughout the day, with a noted increase during the noon hour and again between 4:30 and 6:00 pm. Soon after 6:00, I noticed that the volume dropped to almost zero. In past 
elections, there was usually a rush of people coming from work, trying to get to vote before the polls closed."

Clerk of Elections, Okaloosa County, Precinct No. 34: "As the Clerk, my duties included working the books, instructing people to vote, and handling the ballots, and making sure that things go smoothly and courteously. When the doors were open, there were about 50-60 people waiting in line to vote. During the rest of day, there was a constant flow of voters. We were expecting a rush after Hurlburt Field let out about 4:30. I began to get may workers to take their dinner breaks before 6:00 anticipating people coming before the polls closed. Between 6:15 and 6:20, I looked around and asked, 'Where is everybody?' My poll workers were just as perplexed as I was. I don't think we had more than five people from 6:15 until we closed at 7:00. We had averaged 80 voters per hour until the last hour."

Deputy for Elections, Santa Rosa County, Precinct No. 34: "On Tuesday, November 7, 2000, I was on duty and worked at the precinct from 6:00 am until 8:00 pm. We have the second largest precinct in the county with 4,678 voters. I kept track of the numbers of voters per hour. There were many voters waiting to vote in the first hour and then there was a steady flow all day. By the last hour, there was a dramatic decline in voters. It is the deputy's job to stand behind the last voter in line at 7:00 pm. Eight years ago in the presidential election, there were so many people in line that the last voter did not vote until nearly $10: 30 \mathrm{pm}$. When I went outside at the end of the day to tell people to hurry along, there was no one in the parking lot."

The western Panhandle counties are extremely heavily Republican and Bush obtained about two-thirds of the vote there. An early call that the polls were closed in the entire state when this extremely heavily Republican portion of the state still had an hour to vote could have made the Presidential election a cliff hanger, when it never should have been close. When combined with the network calls for Michigan and Pennsylvania, the Florida call may have influenced elections across the western half of the country where voting was still taking place, because it appeared as if Gore had won the presidential election. Yet, anecdotal evidence is hardly convincing. Surely those who made the above quotes may not be completely disinterested parties and undoubtedly people know why they are being asked to provide these statements. Polls of voters after the fact are also suspect for similar reasons. This paper provides the first systematic evidence of the impact that early election calls have on voter rates. Two types of evidence are provided: (i) pooled time-series, crosssectional data on voting rates for Florida counties in presidential elections from 
1976 to 2000 and (ii) data collected by the Florida Secretary of State's Office on voting turnout rates during the during the November 7, 2000 election.

\section{The Evidence}

As mentioned earlier, a general drop off in voter turnout in a predominantly Republican district causes more of a drop off in absolute terms for Republicans. Telling voters either that the polls are closed when they are not or that the election has already been called for one of the candidates will discourage voters from voting. It is difficult to think of any reason whatsoever why this would increase turnout. ${ }^{7}$

However, there might also be a relative drop off in the rate at which Republicans voted relative to Democrats. The calls that the Democratic Senate candidate and A1 Gore were going to win could have discouraged both Republicans and Democrats from voting, though anecdotal evidence from the 1980 election suggests that those voting for the losing candidates might have been more easily discouraged. ${ }^{8}$ This paper attempts to provide the first systematic evidence that this differential effect exists.

The first evidence uses county level data for the seven Presidential elections from 1976 to 2000 (see data appendix). The rate at which Republicans voted is measured as the natural log of the number of Republican voters divided by the number of registered Republican voters. To account for the premature call that the polls were closed and that Gore had carried Florida, a dummy variable is set to one for the western Panhandle counties in 2000, zero for other counties or for other years.

Besides county and year fixed effects, other control variables were also included. The simplest variable to pick up differences in county turnout over time is the rate at which non-Republicans are voting [In (number of non-Republican voters/number of registered non-Republican voters)]. Factors that cause nonRepublicans to change the rate at which they vote (e.g., the closeness of elections) may also alter the rate at which Republicans vote. To measure trends in Republican turnout several different lagged values of Republican voting rates are included. Finally, besides county and year fixed effects, the factors that I accounted for are the percent of the adult population that are female, black, between different ages (20-29, 30-39, 40-49, 50-64, and 65 and over), per capita personal income, and population density. The results are reported with and without this last set of factors because while they may independently affect the rate at which Republicans voted, they may also impact the rate that Republicans voted through the rate that non-Republicans voted. (The descriptive information on these variables is reported in Table 1.)

The results reported in Table 2 clearly show an unusual drop-off in Republican turnout in Florida's 10 western Panhandle counties in 2000. This drop occurs not only relative to the rate experienced by those very same counties 
Table 1. Descriptive information on variables

\begin{tabular}{|c|c|c|c|}
\hline \multirow{2}{*}{$\begin{array}{l}\text { Variable } \\
\text { In(number of Republican voters/ } \\
\text { number of registered Republican } \\
\text { voters) }\end{array}$} & \multicolumn{2}{|c|}{ Observations Mean } & \multirow{2}{*}{$\frac{\text { Standard deviation }}{1.023281}$} \\
\hline & 469 & 0.7307484 & \\
\hline $\begin{array}{l}\text { In(numbter of non-Republican } \\
\text { voters/number of registered } \\
\text { non-Republican voters) }\end{array}$ & 469 & -0.8077057 & 0.4163269 \\
\hline $\begin{array}{l}\text { Percent of the adult population that } \\
\text { are black }\end{array}$ & 469 & 0.1067293 & 0.0698373 \\
\hline $\begin{array}{l}\text { Percent of the adult population that } \\
\text { are female }\end{array}$ & 469 & 0.3572636 & 0.0426688 \\
\hline $\begin{array}{l}\text { Percent of the population that are } \\
\text { adults between } 20 \text { and } 29\end{array}$ & 469 & 0.1166657 & 0.0811262 \\
\hline $\begin{array}{l}\text { Percent of the population that are } \\
\text { adults between } 30 \text { and } 39\end{array}$ & 469 & 0.1389386 & 0.0234068 \\
\hline $\begin{array}{l}\text { Percent of the population that are } \\
\text { adults between } 40 \text { and } 49\end{array}$ & 469 & 0.1642983 & 0.1461918 \\
\hline $\begin{array}{l}\text { Percent of the population that are } \\
\text { adults between } 50 \text { and } 64\end{array}$ & 469 & 0.1549162 & 0.0273246 \\
\hline $\begin{array}{l}\text { Percent of the population that are } \\
\text { adults over age } 64\end{array}$ & 469 & 0.1406158 & 0.0945202 \\
\hline $\begin{array}{l}\text { One year lag of In(number of } \\
\text { republican voters/number of } \\
\text { registered Republican voters) }\end{array}$ & 402 & 0.8132903 & 1.05572 \\
\hline $\begin{array}{l}\text { Two year lag of In(number of } \\
\text { Republican voters/number of } \\
\text { registered Republican voters) }\end{array}$ & 335 & 0.96601 & 1.04868 \\
\hline $\begin{array}{l}\text { Three year lag of In(number of } \\
\text { Republican voters/number of } \\
\text { registered Republican voters) }\end{array}$ & 268 & 1.116967 & 1.036148 \\
\hline Population density per square mile & 469 & 1277.037 & 4282.774 \\
\hline $\begin{array}{l}\text { Real per capita personal income in } \\
\text { 1982-1983 dollars }\end{array}$ & 469 & 11257.54 & 3577.214 \\
\hline
\end{tabular}

in the six previous Presidential elections, but also relative to the other 57 counties in Florida, counties which were on EST and thus not affected by the early election call. The simplest specification in column 1 , which has just the dummy variable for the early media call and fixed county and year effects indicates an incredibly large 31\% drop in Republican voting rates for those 10 counties in 2000. Even including measures in column 2 of the rate at which non-Republicans turn out and the other demographic, population, and income control variables leaves the result virtually unchanged. The estimates in the second column indicate that there is a $95 \%$ probability that the relative 
Table 2. Explaining the rate at which Republicans voted relative to non-Republicans in Florida counties in presidential elections from 1976 to 2000 (ordinary least square estimates. Robust standard errors are reported. Fixed county and year effects not reported)

Endogenous variable

$\ln$ (number of republican voters/number of registered Republican voters)

\begin{tabular}{|c|c|c|c|c|c|c|}
\hline Exogenous variables & (1) & (2) & (3) & (4) & (5) & (6) \\
\hline Dummy variable for western & -.2901 & -.2961 & -.2911 & -.208 & -.236 & -.166 \\
\hline Panhandle counties in 2000 & $(2.24)$ & $(3.72)$ & $(3.13)$ & $(2.36)$ & $(2.52)$ & $(2.33)$ \\
\hline $\begin{array}{l}\ln \text { (number of non-Republican } \\
\text { voters/number of registered } \\
\text { non-Republican voters) }\end{array}$ & - & $\begin{array}{l}.5270 \\
(6.09)\end{array}$ & $\begin{array}{l}.3936 \\
(5.07)\end{array}$ & $\begin{array}{l}.3961 \\
(4.55)\end{array}$ & $\begin{array}{l}.454 \\
(4.09)\end{array}$ & $\begin{array}{l}.540 \\
(4.26)\end{array}$ \\
\hline $\begin{array}{l}\text { One election lag of In(number } \\
\text { of Republican voters/number } \\
\text { of registered Republican } \\
\text { voters) }\end{array}$ & - & - & - & $\begin{array}{l}.223 \\
(2.60)\end{array}$ & $\begin{array}{l}.153 \\
(1.30)\end{array}$ & $\begin{array}{l}.126 \\
(2.03)\end{array}$ \\
\hline $\begin{array}{l}\text { Two election lag of } \ln \text { (number } \\
\text { of Republican voters/number } \\
\text { of registered Republican } \\
\text { voters) }\end{array}$ & - & - & - & - & $\begin{array}{l}-.0357 \\
(0.48)\end{array}$ & $\begin{array}{l}-.004 \\
(.06)\end{array}$ \\
\hline $\begin{array}{l}\text { Three election lag of } \\
\ln \text { (number of Republican } \\
\text { voters/number of registered } \\
\text { Republican voters) }\end{array}$ & - & - & - & - & - & $\begin{array}{l}.050 \\
(1.04)\end{array}$ \\
\hline $\begin{array}{l}\text { Population density per square } \\
\text { mile }\end{array}$ & - & - & $\begin{array}{l}-3.14 \mathrm{e}-6 \\
(0.45)\end{array}$ & $\begin{array}{l}-1.15 \mathrm{e}-6 \\
(0.19)\end{array}$ & $\begin{array}{l}1.13 \mathrm{e}-7 \\
(0.002)\end{array}$ & $\begin{array}{l}7.88 \mathrm{e}-7 \\
(0.16)\end{array}$ \\
\hline $\begin{array}{l}\text { Real per capita personal } \\
\text { income }\end{array}$ & & & $\begin{array}{l}-1.73 \mathrm{e}-5 \\
(1.23)\end{array}$ & $\begin{array}{l}-1.89 \mathrm{e}-5 \\
(1.37)\end{array}$ & $\begin{array}{l}-1.17 \mathrm{e}-5 \\
(0.731)\end{array}$ & $\begin{array}{l}-1.69 \mathrm{e}-5 \\
(0.92)\end{array}$ \\
\hline $\begin{array}{l}\text { Percent of the adult population } \\
\text { that are black }\end{array}$ & - & - & $\begin{array}{l}-2.04 \\
(1.56)\end{array}$ & $\begin{array}{l}-3.32 \\
(2.28)\end{array}$ & $\begin{array}{l}-8.614 \\
(4.27)\end{array}$ & $\begin{array}{l}-8.81 \\
(5.50)\end{array}$ \\
\hline $\begin{array}{l}\text { Percent of the adult population } \\
\text { that are female }\end{array}$ & - & - & $\begin{array}{l}-1.93 \\
(3.93)\end{array}$ & $\begin{array}{l}-1.22 \\
(2.81)\end{array}$ & $\begin{array}{l}-1.27 \\
(2.70)\end{array}$ & $\begin{array}{l}-.617 \\
(1.745)\end{array}$ \\
\hline $\begin{array}{l}\text { Percent of the population that } \\
\text { are adults between } 20 \text { to } 29\end{array}$ & - & - & $\begin{array}{l}-1.81 \\
(1.13)\end{array}$ & $\begin{array}{l}-.923 \\
(0.45)\end{array}$ & $\begin{array}{l}-.093 \\
(0.03)\end{array}$ & $\begin{array}{l}-2.28 \\
(1.57)\end{array}$ \\
\hline $\begin{array}{l}\text { Percent of the population that } \\
\text { are adults between } 30 \text { to } 39\end{array}$ & - & - & $\begin{array}{l}.629 \\
(0.23)\end{array}$ & $\begin{array}{l}1.449 \\
(0.52)\end{array}$ & $\begin{array}{l}-0.52 \\
(0.02)\end{array}$ & $\begin{array}{l}2.545 \\
(1.11)\end{array}$ \\
\hline $\begin{array}{l}\text { Percent of the population that } \\
\text { are adults between } 40 \text { to } 49\end{array}$ & - & - & $\begin{array}{l}-.641 \\
(0.52)\end{array}$ & $\begin{array}{l}-.001 \\
(0.00)\end{array}$ & $\begin{array}{l}.788 \\
(0.43)\end{array}$ & $\begin{array}{l}-.672 \\
(0.64)\end{array}$ \\
\hline $\begin{array}{l}\text { Percent of the population that } \\
\text { are adults between } 50 \text { to } 64\end{array}$ & - & - & $\begin{array}{l}-5.30 \\
(2.80)\end{array}$ & $\begin{array}{l}-3.811 \\
(3.69)\end{array}$ & $\begin{array}{l}-4.58 \\
(3.97)\end{array}$ & $\begin{array}{l}-3.34 \\
(3.23)\end{array}$ \\
\hline $\begin{array}{l}\text { Percent of the population that } \\
\text { are adults over age } 64\end{array}$ & - & - & $\begin{array}{l}-.174 \\
(0.15)\end{array}$ & $\begin{array}{l}.575 \\
(0.55)\end{array}$ & $\begin{array}{l}1.020 \\
(0.92)\end{array}$ & $\begin{array}{l}.620 \\
(0.68)\end{array}$ \\
\hline$F$-Statistic & 137.52 & 154.42 & 91.48 & 96.60 & 82.85 & 55.03 \\
\hline $\operatorname{Adj} R^{2}$ & .8919 & .9225 & .9349 & .9316 & .9336 & .9472 \\
\hline Numbers of observations & 469 & 469 & 469 & 402 & 335 & 268 \\
\hline
\end{tabular}

decline in Republican voting rates was at least equal to the $4.4 \%$ found in the McLaughlin \& Associates survey.

Yet, looking at the data reveals that there is a downward trend over time in the rate at which Republicans are voting in the western Panhandle. Even 
as the share of Republican votes in the western Panhandle has been rising, the intensity with which Republicans turn out to vote has been abating. The lagged Republican voting rates in columns 3-5 account for this trend and imply a much smaller drop in Republican turnout. Depending upon number of lags used, the drop of in the Republican voting rate is between 15 and $23 \%$ and is statistically significant at least at the $8 \%$ level for a twotailed $t$-test. The third column indicates that there is at least an $89 \%$ probability that the decline in Republican voting rates was at least equal to the 4.4 drop relative to Democrats that was claimed by McLaughlin \& Associates. The fourth and fifth columns imply that this probability is respectively 91 and $79 \%$.

Table 2 also makes another point clear. The estimated drop in Republican voting rates essentially remains unchanged whether or not the nonRepublican voting rate variable is included. Indeed this is true even when the non-Republican voting rate is excluded from specifications three through five. What this implies is that the non-Republican voting rate did not decline during the 2000 general election in the western Panhandle. This is further confirmed when the regressions shown in Table 2 were reestimated to explain the non-Republican voting rate. This result seems much more consistent with the media deterring Republican voters by prematurely calling the races for the Democrats in the Senate and Presidential races than it supports the notion that telling the voters that the polls were closed generally discouraged voters in the western Panhandle.

There is the issue of whether this drop off in Republican voting is actually a result of unique circumstances in a few of the counties. Any impact of the media should have affected all the counties, while unusual county level races would have affect only a portion of the counties. Fortunately, this is easily examined. Table 3 breaks down the results for all the regressions shown Table 2 for the western Panhandle counties for 2000 dummy by individual county. Obviously, each one of these dummy variables is now only equal to one for only one observation and thus, it will be difficult to obtain statistically significant results, but the results are remarkably consistent. Fifty-one out of the 60 county coefficients imply that the voting rates for Republicans fell in the 2000 Presidential election, and 37 of those 51 coefficients are statistically significant at least at the $10 \%$ level for a two-tailed $t$-test. Only two coefficients for Escambia county are both positive and statistically significant. Assuming a $50 \%$ probability that the Republican voting rate in any individual county will fall, there is a $2 \%$ probability that nine of the ten counties in any regression should show a decline in Republican voting rates.

Escambia is the one western Panhandle county that consistently implies across all the specifications that the voting rate of Republicans actually rose in 2000. A Nexis search does not indicate why this is the case. Five-and-ahalf of the western Panhandle counties are in the first Congressional district 


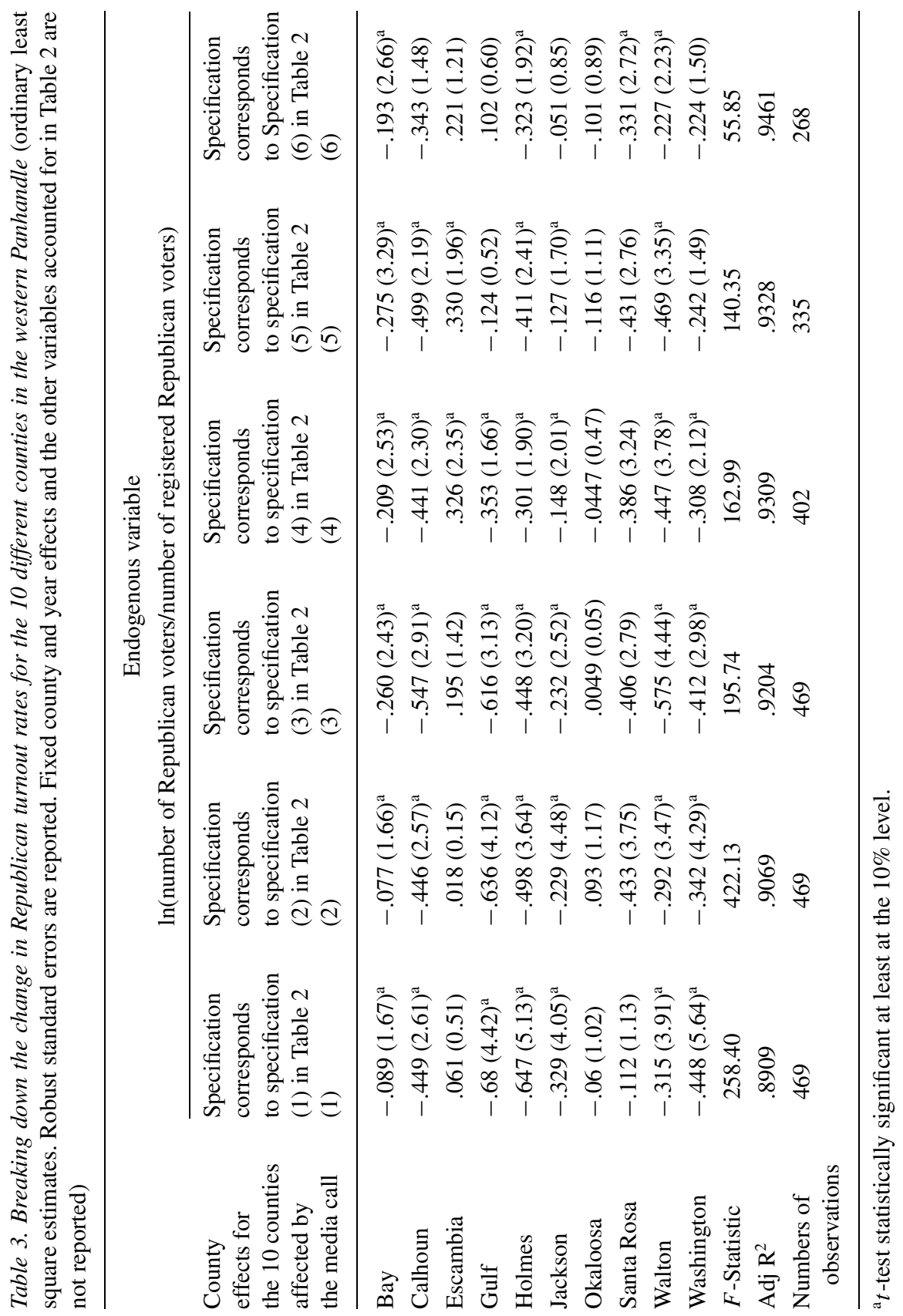


Table 4. Cross-county evidence examining voting over the whole day compared to voting rates by late morning (ordinary least square estimates. Robust standard errors are reported)

\begin{tabular}{|c|c|c|}
\hline \multirow[b]{2}{*}{ Exogenous variables } & \multicolumn{2}{|c|}{$\begin{array}{l}\text { Endogenous variable } \\
\ln \text { (number of Republican voters/number } \\
\quad \text { of registered Republican voters) }\end{array}$} \\
\hline & (1) & (2) \\
\hline $\begin{array}{l}\text { Dummy variable for western } \\
\text { Panhandle counties in } 2000\end{array}$ & $\begin{array}{l}-.031 \\
(0.910)\end{array}$ & $\begin{array}{l}-.045 \\
(1.099)\end{array}$ \\
\hline $\begin{array}{l}\text { Voting turnout rate in county by } \\
\text { late morning }\end{array}$ & $\begin{array}{l}-.0081 \\
(0.845)\end{array}$ & $\begin{array}{l}-.0098 \\
(0.907)\end{array}$ \\
\hline $\begin{array}{l}\ln (\text { number of non-Republican } \\
\text { voters/number of registered } \\
\text { non-Republican voters }\end{array}$ & $\begin{array}{l}.265 \\
(3.783)\end{array}$ & $\begin{array}{l}.283 \\
(3.853)\end{array}$ \\
\hline $\begin{array}{l}\text { One year lag of } \ln \text { (number of } \\
\text { Republican voters/number of } \\
\text { registered Republican voters) }\end{array}$ & $\begin{array}{l}.370 \\
(4.388)\end{array}$ & $\begin{array}{l}.384 \\
(4.315)\end{array}$ \\
\hline $\begin{array}{l}\text { Two year lag of } \ln \text { (number of } \\
\text { Republican voters/number of } \\
\text { registered Republican voters) }\end{array}$ & $\begin{array}{l}.120 \\
(1.099)\end{array}$ & $\begin{array}{l}.1044 \\
(0.896)\end{array}$ \\
\hline $\begin{array}{l}\text { Three year lag of } \ln \text { (number of } \\
\text { Republican voters/number of } \\
\text { registered Republican voters) }\end{array}$ & $\begin{array}{l}.374 \\
(5.027)\end{array}$ & $\begin{array}{l}.386 \\
(4.895)\end{array}$ \\
\hline Population density per square mile & $\begin{array}{l}-4.65 \mathrm{e}-6 \\
(1.579)\end{array}$ & $\begin{array}{l}-5.44 \mathrm{e}-6 \\
(1.805)\end{array}$ \\
\hline $\begin{array}{l}\text { Percent of the adult population } \\
\text { that are black }\end{array}$ & $\begin{array}{l}-1.049 \\
(4.893)\end{array}$ & $\begin{array}{l}-1.006 \\
(4.569)\end{array}$ \\
\hline $\begin{array}{l}\text { Percent of the adult population } \\
\text { that are female }\end{array}$ & $\begin{array}{l}.265 \\
(0.978)\end{array}$ & $\begin{array}{l}.179 \\
(0.640)\end{array}$ \\
\hline Real per capita personal income & $\begin{array}{l}-4.45 \mathrm{e}-6 \\
(0.864)\end{array}$ & $\begin{array}{l}-6.69 \mathrm{e}-6 \\
(1.247)\end{array}$ \\
\hline $\begin{array}{l}\text { Percent of the population that are } \\
\text { adults between } 20 \text { and } 29\end{array}$ & - & - \\
\hline $\begin{array}{l}\text { Percent of the population that are } \\
\text { adults between } 30 \text { and } 39\end{array}$ & - & - \\
\hline $\begin{array}{l}\text { Percent of the population that are } \\
\text { adults between } 40 \text { and } 49\end{array}$ & $\begin{array}{l}.174 \\
(1.773)\end{array}$ & - \\
\hline $\begin{array}{l}\text { Percent of the population that are } \\
\text { adults between } 50 \text { and } 64\end{array}$ & $\begin{array}{l}-1.68 \\
(2.231)\end{array}$ & - \\
\hline $\begin{array}{l}\text { Percent of the population that are } \\
\text { adults over age } 64\end{array}$ & - & - \\
\hline$F$-statistic & 161.74 & 173.52 \\
\hline Adj $R^{2}$ & .9725 & .9688 \\
\hline Numbers of observations & 51 & 51 \\
\hline
\end{tabular}


and four-and-a-half are in the second. Why only one of the five counties in the first Congressional district show an increase is not clear. The one unique feature about that is mentioned in the press coverage is the very high rate that retired military officers were moving to Escambia during the late 1990s. Possibly these retired military officers not only vote Republican but also vote at relatively high rates.

An additional test was also done. The Florida Secretary of State's office collects information on election morning turnout rates, where turnout is rated as either 'light', 'medium', 'steady', 'heavy' or something greater than heavy. The data allow a test for whether there was a relative drop during the day in voting for 7 of the 10 western Panhandle counties for which the Secretary of State received reports. For the 2000 Presidential election, the morning turnout in these seven western Panhandle counties was actually $12 \%$ higher than the 44 counties in the rest of the state that also reported this information. Ideally, it would be preferred to have a better measure of turnout and this noise undoubtedly biases any results toward zero, but we assign values of $1-6$ for these six different levels. It would also be valuable to have this information across multiple years, but it was only available for 2000 and for only 51 of the 57 counties. This last point is important because the western Panhandle counties may have a different pattern of voting over the day than the other counties in the state. For example, it is possible that relatively more of voters in the western Panhandle vote during the morning. The only way to account for that would have been to have information on voting patterns during the morning across different years. Unfortunately, because of these deficiencies and the fact that this data are purely cross-sectional means that this test can only be viewed as suggestive.

The same control variables as used before are employed here, though the past rates of Republican voting rates are included in both specifications because with this cross-sectional data, it is no longer possible to include county level dummy variables. Despite accounting for the level of morning turnout, the regressions reported in Table 3 show that the seven western Panhandle counties where the data were available had a 3 or $4.5 \%$ smaller growth in Republican turnout relative to counties in the rest of the state. However, the results using this much smaller sample are only suggestive, since they are not significant at normally accepted levels. The impact is only significant at the $17 \%$ level for a one-tailed $t$-test. This suggests that the preponderance of the evidence supports the conclusion that there was an unusual drop in Republican votes during the last part of the day, but additional work should be done to see if this last sample can be expanded back to earlier elections. ${ }^{9}$

\section{Conclusion}

Something unusual happened to Republican voting rates in Florida's western Panhandle in the 2000 general election. To put these results in perspective, 
each one percent drop in Republican turnout relative to the non-Republicans in the western Panhandle represents about 2500 votes-a drop of about 7 votes per precinct. The drop of at least $15 \%$ implied by the pooled cross-sectional time-series data suggests that there were 37500 fewer votes for Bush, 105 fewer votes per precinct. If anything, these results seem too large particularly if the effect of the media coverage was only to discourage Republican voters, even though voters vote at disproportionately high rates during the last hour that polls are open. But clearly something unusual occurred in the 2000 Presidential election. Even the purely cross-sectional estimates imply that Bush received as many as 7500 to 10000 fewer votes than he would normally have expected later in the day.

To put the size of these results in perspective, USA Today and the Miami Herald indicated that their recounts of the Florida ballots would have produced anything from a Bush win of 1665 votes, if the Florida Supreme Court's ruling had been followed to an 885 vote Bush Victory if the Palm Beach standard had been used to a three-vote Gore win if only fully punched ballots without hanging chads been counted (Cauchon, 2001). Other vote recounting by USA Today and the Miami Herald indicates that Gore may have lost 15,000 votes as a result of West Palm Beach County voters voting for multiple Presidential candidates (Cauchon \& Drinkard, 2001).

While the Beckel and John McLaughlin \& Associates surveys have the distinct advantage over the regressions presented here of asking voters whether they heard the early call and whether it altered their behavior, it also has the disadvantage of relying on people accurately relating what happened. An example of this problem arises in surveys of voters after elections where a much larger percent of voters frequently claim to have voted for the winner than is possible. Fortunately, both the McLaughlin survey as well as my own work provides consistent estimates.

\section{Acknowledgements}

I would like to thank Gertrud Fremling, Steve Bronars, and Larry Kenny for helpful comments. Maxim Lott also provided very valuable research assistance.

\section{Notes}

1. There are several studies that were done on the 1980 election, though two of the studies (Jackson, 1983; Carpini, 1984) are purely cross-sectional based on either turnout or survey data with few controls and a third study (Epstein \& Strom, 1981) simply compares the change in turnout rates for western states compared to other states. See also Mason, Frankovic, and Jamieson (2001) for a discussion of the lack of research on this topic.

2. Tony Snow See also Mason, Frankovic, and Jamieson (2001, p. 44).

3. Ibid.

4. CNN Inside Politics, CNN, Tuesday, May 15, 2001. 
5. Bill Sammon, 'Networks' early call kept many from polls, Florida section affected by TV,' Washington Times, Monday, May 7, 2001, p. A1. McLaughlin \& Associates is a Republican polling organization, so its estimates are possibly suspect. See also Sammon (2001).

6. For some papers on the economics of deciding whether to vote see Crain, Shughart, and Tollison (1988) and Tollison (1973).

7. Even if some people knew that the early call was erroneous and that other voters were being falsely led not to vote, it seems doubtful that many of these informed people could be induced to now vote because their vote was somehow more valuable as a result of the low turnout. More importantly, this increase in voting by 'informed' people could not offset the reduction in voters who were making a mistake, because as the rate of voting by informed voters rose, it would reduce their return to voting.

8. Marc Lacey, "Early Concession Statement is Dole Camp's Final Blunder," Los Angeles Times, November 6, 1996, p. A19 and San Francisco Examiner editorial, "TV's premature projections," San Francisco Examiner, November 7, 1996, p. A20.

9. I have tried unsuccessfully to obtain this data, but, despite numerous telephone calls to the Florida Secretary of State's office, I was unsuccessful.

\section{Appendix}

The data on Florida elections from 1976 to 1996 is all derived from the Florida Statistical Abstract. Data for the 2000 general election on voter registration was obtained from the Florida Secretary of State's web site and CNN's final county level vote tally for the presidential vote. Population and demographic information is from the U.S. Census Bureau. The income measure is from the Bureau of Economic Analysis, Regional Accounts Data, Annual State Personal Income-http://www.bea.doc.gov/bea/regional/spi/. Table SA30. All dollar values are in Real' 1982-1983 dollars (average of those two years)-Consumer Price Index conversion factors based on table at: http://www.orst.edu/Dept/pol_sci/fac/sahr/cv98.htm.

Unfortunately, since the control data was not available for 2000 , we tried to approaches: 1) running the regressions without the control variables and 2) using data from 1998 in our estimates for 2000.

\section{References}

Carpini, M. S. D. (1984). Scooping the voters? The consequences of the networks' early call of the 1980 presidential race. Journal of Politics, 46(3), 866-885.

Cauchon, D. (2001). Special report: Newspapers' recount shows Bush prevailed in Florida Vote. USA Today. p. A1.

Cauchon, D., \& Drinkard, J. (2001). Special report: Florida voter errors cost Gore the election, Bush still prevails in recount of all disputed ballots, using two most common standards. USA Today. p. A1.

Crain, W. M., William, F. S., \& Robert, D. T. (1988). Voters as investors: A rent-seeking resolution of the paradox of voting. In C. K. Rowley, R. D. Tollison, \& G. Tullock (Eds.), The political economy of rent seeking (pp. 241-249). Boston, MA: Kluwer-Nijhoff.

Epstein, L. K., \& Gerald, S. (1981). Election night projections and West Coast turnout. American Politics Quarterly, 9(4), 479-491. 
Jackson, J. E. (1983). Election night reporting and voter turnout. American Journal of Political Science, 27(4), 615-635.

Mason, L., Kathleen, F., \& Kathleen, H. J. (2001). CBS news coverage of election night 2000: Investigation, analysis, recommendations. CBS News.

Perrin, D. B. (2001). Testimony federal elections, The Senate government affairs committee on federal elections. Federal Document Clearing House, May 3, 2001.

Sammon, B. (2001). At any cost: How Al Gore tried to steal the election. Washington, D.C.: Regnery Publishing, Inc.

Tollison, R. D. (1973). Some notes on the simple economics of voting and not voting. Public Choice, 59-71. 